K

STUDIA Z PRAWA WYZNANIOWEGO

Tom $21-2018$

DOI: https://doi.org/10.31743/spw.184

DIMITRY GEGENAVA*

\title{
CHURCH-STATE RELATIONS IN THE DEMOCRATIC REPUBLIC OF GEORGIA (1918-1921)
}

\section{Summary}

Democratic Republic of Georgia (1918-1921) was one of the unique states in the first quarter of XX century. Despite the historical relations between the Church and the State in Georgia, the social-democratic government changed its official policy and chose French secularism, which was very unusual for the country. This was incorporated in the Constitution of 1921. This article is about the Georgian church-state relations during 1918-1921, the positive and negative aspects of the chosen form of secularism and the challenges that the newly independent State faced in the sphere of religious freedom until the Soviet occupation.

Key words: Georgian Orthodox Church; separation; Democratic Republic of Georgia; freedom of religion; secularism; church-state relations

$* * * * *$

\section{INTRODUCTION}

The Democratic Republic of Georgia was one of the most interesting social-democratic experiments of the last century. During the three years of its existence, the Republic made huge reforms ${ }^{1}$, created an extraordinary

* Doctor of Law, Associate Professor, Vice-Rector of Sulkhan-Saba Orbeliani University, Faculty of Law, Sulkhan-Saba Orbeliani University, 3 Kalistrate Qutateladze St, Tbilisi, 0186, Georgia, e-mail: d.gegenava@sabauni.edu.ge.

1 See: Thierry Berichvili, La social-démocratie géorgienne de 1880 à 1953 -Quelques repères, Tbilissi 2017. 
constitution $^{2}$ and made real the European democracy in East Europe. Unfortunately, Soviet Russia occupied the Democratic Republic of Georgia in 1921 and destroyed all the progressive ideas or results of reforms.

The Social-Democratic Party was the main ruling party of the State and had its own political course with idealistic and sometimes utopist ideas. In 1918-1921, the Georgian government tried to be more French than the French people could. Beside the past models of church-state relations ${ }^{3}$, the government implemented a radical model of secularism, with a strict and painful separation of the Church and the State. The parliament adopted this political direction in ordinary laws and even on the constitutional level.

Neither the religious entities nor the government had any intention to solve the problems in their relations. While there were confrontations, the State implemented a new model of church-state relations, which weakened religious organizations and then made it easy for the Bolsheviks to destroy them finally.

\section{RELIGION AND GEORGIAN CONSTITUTIONAL IDENTITY IN 1918-1921}

For many centuries, the Georgian State and the Orthodox Church were tightly connected with each other; moreover, the Christian Church was the main creator of the national ideology and Georgia, surrounded by Islamic countries, used it intensively as a tool against occupants ${ }^{4}$. This cooperation assumed different forms, sometimes the Church had priority over the

2 Hans Dietrich Gensher, „Introduction”, in: Wolfgang Gaul, Adoption and Elaboration of Constitution in Georgia (1993-1995); Dimitry Gegenava, „Les Bases Européennes Du Constitutionalisme Géorgien: La Lutte Pour Un Etat De Droit", in: Valeurs et Identite Européennes, Texte des Conferences, Tbilissi 2014, 326-336.

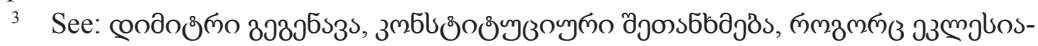

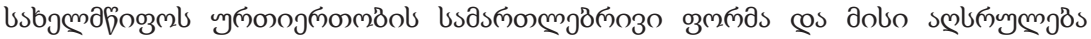

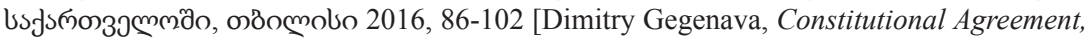
as Legal Form of Church-State Relations and Its Implementation in Georgia, Tbilisi 2016, 86-102].

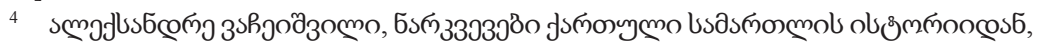
§. II, o8̊omolo 1948, 49. [Alexander Vacheishvili, Outlines of the History of Georgian Law, Vol. II, Tbilisi 1948, 49]. 
State and sometimes the government had a dominant position. This model was very close to the Byzantine system of church-state relations called "Symphony". The Russian Empire occupied the Georgian kingdoms in the beginning of XIX century and implemented anti-nationalist politics against everything that was associated with independence ${ }^{6}$. In 1811, the Empire made an extraordinary decision - it abolished, against canon law, the Georgian Orthodox Church as an autocephalous institution, and merged it with the Russian Church. ${ }^{7}$ Since that moment, the restoration of the autocephaly and independence of the Georgian Church was not only a religious but also a national question.

In 1917, the Russian Empire fell and the Georgian political and religious leaders decided to restore the independence of the Georgian Church, because this fact would be the first sign and important step in restoring the sovereignty of all Georgia ${ }^{8}$. The Georgian political leaders, both Social Democrats and National Democrats in St. Petersburg, helped the Church leaders ${ }^{9}$. Their activities led to the following results: the Georgian spiritual and secular leaders made the Russian temporary government adopt a special rule on "The rights of the Georgian Church in the Russian State" and recognized the autocephalous status of the Georgian Church ${ }^{10}$. According this rule, the Russian government gave assignations to the Church from

5 Norman Doe, Christian Law, Contemporary Principles, New York 2013, 348.

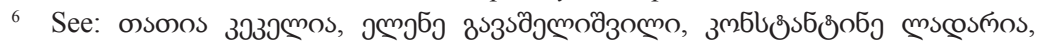

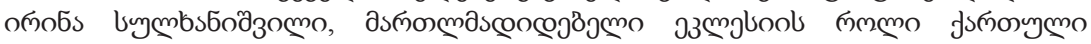

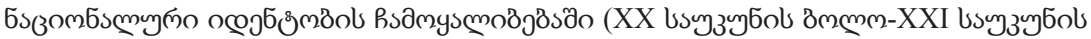
coslusfyolo), o8̊omolo 2013, 16 [Tatia Kekelia, Elene Gavashelishvili, Konstantine Ladaria, Irina Sulkhanishvili, The Role of the Orthodox Church in the Establishment of the Georgian National Identity (End of XX Century-Beginning of XXI Century), Tbilisi 2013, 16.]

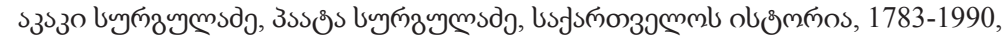
ő̇omobo 1991, 17 [Akaki Surguladze, Paata Surguladze, History of Georgia, 1783-1990, Tbilisi 1991, 17].

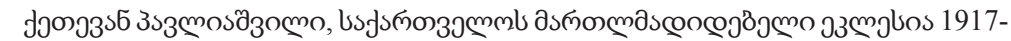

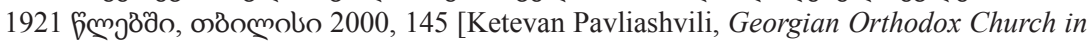
1917-1921, Tbilisi 2000, 145].

$9 \quad$ Ibid, 146.

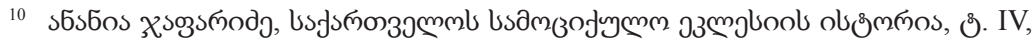
obomolo 2012, 1111 [Anania Japaridze, History of the Georgian Apostolic Church, Vol. IV, Tbilisi 2012, 1111]. 
the State budget and treasury and recognized it as the official inheritor of the Georgian Hexarchy ${ }^{11}$. The Russian government automatically gave the Georgian Church all monasteries, temples, properties of the former Hexarchy despite the Russian clergy's objections ${ }^{12}$.

The political leaders and parties knew that the State could not achieve political independence separately and every basic social institution had to be involved in the process. The Georgian Church was an important ideological mechanism which could unite the whole nation. In 1917, the first council of the Church took place and it announced the restoration of autocephaly and elected a patriarch ${ }^{13}$. The newly elected patriarch Kirion II officially declared the Church's goal - serving for the welfare of the State and helping people in the process of restoring national independence ${ }^{14}$. Symbolically, the spiritual leaders took part in the council meeting when the National Council declared the independence of Georgia ${ }^{15}$. After two days, on 28 May 1918, the Georgian Church declared 26 May (Independence Day) as an official feast of the Church ${ }^{16}$ and created a special loyalty oath of citizens ${ }^{17}$, which aimed to support the State and guarantee the establishment of the rule of law ${ }^{18}$.

11 Ibid.

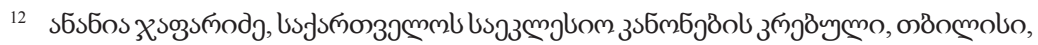
2010, 591 [Anania Japaridze, Code of Georgian Canon Laws, Tbilisi 2010, 591].

13 Ibid.

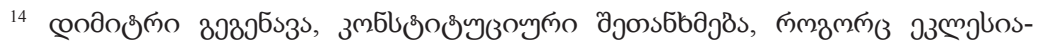

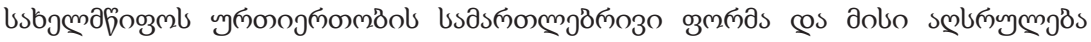

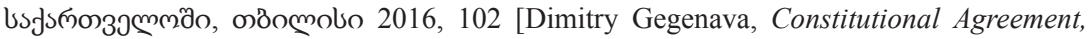
as Legal Form of Church-State Relations and Its Implementation in Georgia, Tbilisi 2016, $102]$.

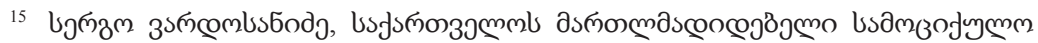

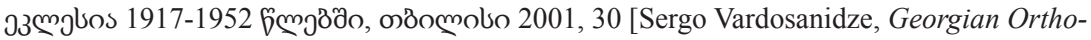
dox Church in 1917-1952, Tbilisi 2001, 30].

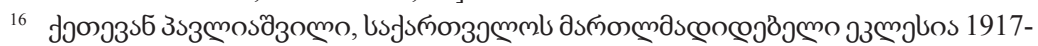

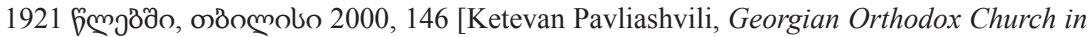
1917-1921, Tbilisi 2000, 146].

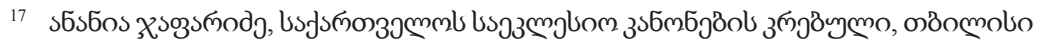
2010, 592 [Anania Japaridze, Code of Georgian Canon Laws, Tbilisi 2010, 592].

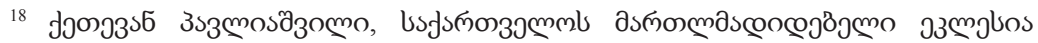

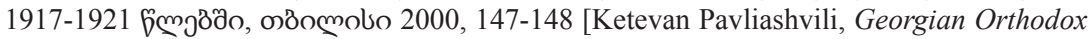
Church in 1917-1921, Tbilisi 2000, 147-148]. 


\section{GEORGIAN GOVERNMENT AND RELIGIOUS POLICY}

The Georgian Social Democrats did not trust churches and religious institutions. The Russian Church was one of the main ideological instruments of tyranny and official enemy of any democratic or liberal ideas in the Empire ${ }^{19}$. The Social Democrats tried to minimize the authority of the Church in the population and banish religious organizations from the everyday life of the society ${ }^{20}$. This policy became the official course of the government when the Social Democrats won the parliamentary elections and achieved an absolute majority.

The government's official policy on church-state relations was destructive and harmful not only for the religious organizations, but for the whole nation in general. It always caused confrontation between the Georgian Church and politicians between 1918-1921. Instead of making spiritual leaders and religious organizations partners in the fight against the Bolsheviks, the government weakened them and declared them unofficial enemies of the State.

In the beginning, during the period of the temporary government, the State budget had special clauses for funding the $\mathrm{Church}^{21}$, but this was changed after the restoration of independence. The national government

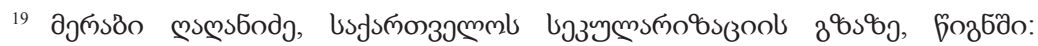

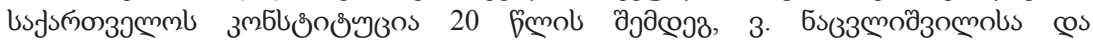

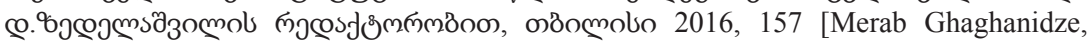
"Georgia on the Way of Secularization", in: Constitution of Georgia after 20 years, edited by V. Natsvlishvili and D. Zedelashvili, Tbilisi 2016, 157].

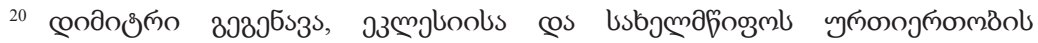

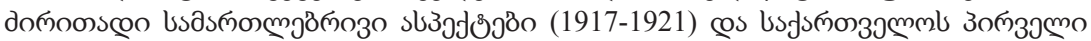

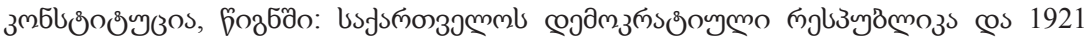

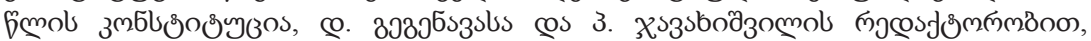
о ̋̇omolo 2013, 174 [Dimitry Gegenava, „Basic Legal Aspects of Relations Between Church and State (1917-1921) and First Constitution of Georgia", in: Democratic Republic of Georgia and Constitution of 1921, edited by Dimitry Gegenava and Paata Javakhishvili, Tbilisi 2013, 174].

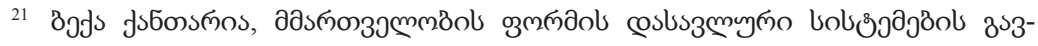

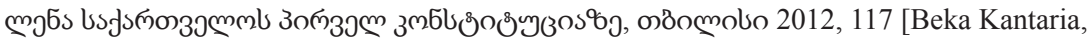
Influence of Western Forms of Government on the First Constitution of Georgia, Tbilisi 2012, 117]. 
adopted a very strict religious policy and carried out actions that harmed religious organizations and religion generally: 1) on 13 September 1918, the National Council of Georgia abolished national divisions of seminaries in Tbilisi and Gori; the Government nationalized and reorganized seminaries of Khoni, Gori and Sokhumi as public schools ${ }^{22}$; the Ministry of Education subordinated all spiritual schools ${ }^{23}$; 2) on 26 November 1918, the government prohibited teaching religion at all public and private schools ${ }^{24} ; 3$ ) on 3 December 1918, the Georgian Church was deprived of the rights of civil registry ${ }^{25}$; 4) on 17 June 1919, the Founding Council (parliament) reduced rest days by annulling numbers of religious feasts ${ }^{26}$; 5) on 21 May 1920, the government of the Democratic Republic of Georgia adopted a decree and expropriated treasure and property of the $\mathrm{Church}^{27}$; the Church had objections on this point and demanded at least the return of its treasure (icons, crosses, etc.); the reaction of head of the government to the demands was as follows: "I will not bear a state in the State"28; 6) the Republic interfered in the internal affairs of the Church, tried to define its basic directions and even influence its personnel policy ${ }^{29}$.

The Democratic Republic of Georgia carried out an agricultural reform. The government did not return the lands and retails expropriated by

22 Law of National Council and Republic of Georgia on "Nationalization of Teachers Institutions and Seminaries".

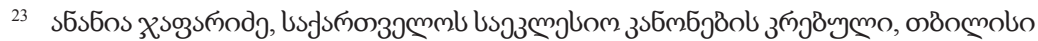
2010, 593 [Anania Japaridze, Code of Georgian Canon Laws, Tbilisi 2010, 593].

24 Law of National Council and Republic of Georgia on "Abolition Religious Teaching".

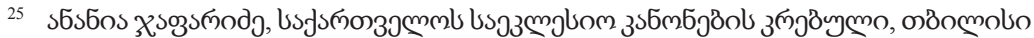
2010, 593 [Anania Japaridze, Code of Georgian Canon Laws, Tbilisi 2010, 593].

26 Law of Founding Council and Republic of Georgia on "Reducing Number of Rest Days".

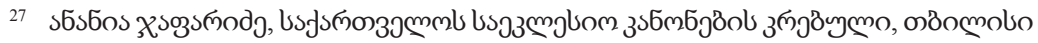
2010, 593 [Anania Japaridze, Code of Georgian Canon Laws, Tbilisi 2010, 593].

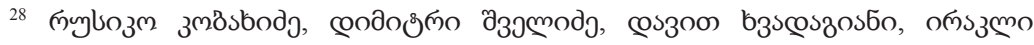

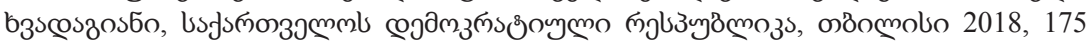
[Rusiko Kobakhidze, Dimitri Silakadze, David Khvadagiani, Irakili Khvadagiani, Democratic Republic of Georgia, Tbilisi 2018, 175].

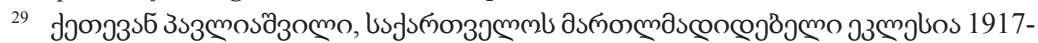

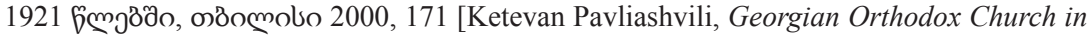
1917-1921, Tbilisi 2000, 171]. 
the Russian Empire, but also confiscated a certain amount of lands owned by the Georgian Church even during existence of the Hexarchy ${ }^{30}$.

The government annulled the Caucasian Synodal Cantor, which was the official organ of the Russian Church and Empire in Georgia, and this gave broad opportunities to the national Church for future operations ${ }^{31}$. In 1920, the Minister of Justice gave a special report on the condition of the Russian, Greek and Osetian Orthodox parishes in Georgia ${ }^{32}$. The Minister of Interior Affairs transferred them to the Georgian $\mathrm{Church}^{33}$, but it was for the benefit of the State to guarantee the unity and stability of State security.

In September-November of 1920, the State worked out a bill on "the Separation of Church and State". This bill was clearly anti-religious and against religious organizations. It consisted of 24 articles and it did not so much express the concept of State secularity as it involved the deprivation of all functions and rights from churches ${ }^{34}$. According to the bill, churches had to pay special additional taxes and a breach of this obligation was a criminal act $^{35}$.

After serious debates, a special commission of the parliament adopted only 5 articles. They expressed the following ideas: 1) religious neutrality; 2) freedom of religion and conscience; 3 ) prohibition of funding religious organizations and religion from national or municipal budgets, except for salaries for priests in hospitals, jails or the army (this article made an exception for temples and religious buildings with a cultural heritage status); 4) granting religious organizations the right to create special entities for

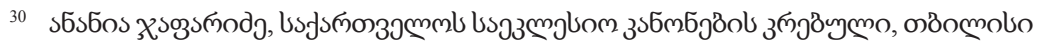
2010, 593 [Anania Japaridze, Code of Georgian Canon Laws, Tbilisi 2010, 593].

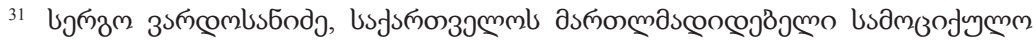

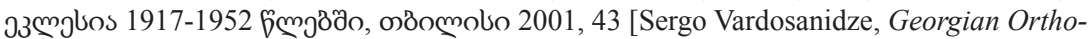
dox Church in 1917-1952, Tbilisi 2001, 43].

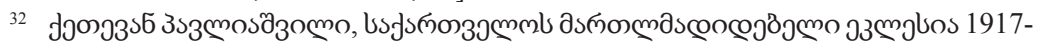

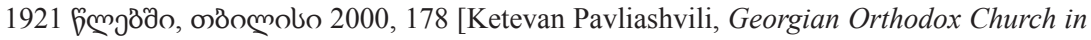
1917-1921, Tbilisi 2000, 178].

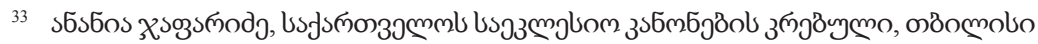
2010, 593 [Anania Japaridze, Code of Georgian Canon Laws, Tbilisi 2010, 593].

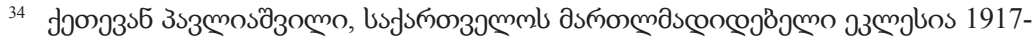

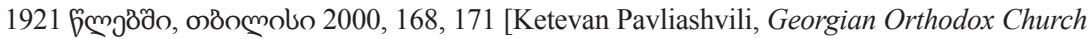
in 1917-1921, Tbilisi 2000, 168, 171].

35 Ibid, 172. 
solving financial questions; 5) limiting the right to acquire legal personality to religious organizations that had only non-commercial, non-profitmaking goals were able to obtain the status of legal entities ${ }^{36}$.

\section{CONSTITUTION OF 1921 AND CHURCH-STATE RELATIONS}

\subsection{ISSUES PERTAINING TO LAW ON RELIGION IN THE PROCESS OF DRAFTING THE CONSTITUTION}

The Constitutional Commission of the parliament discussed the chapter on the Church and the State on 24 February $1919^{37}$. This part of the Constitution was one of the most clear and most extensively discussed and debated ones. Giorgi Naneishvili and Razhden Arsenidze presented two projects of the articles. Naneishvili's project intended implementation of French secularism (Laïcité) in Georgia, whereas Arsenidze's version was closer to liberal secularism. Arsenidze was against "radical" clauses and suggested to adopt the article from the first amendment of the U.S. Constitution to avoid the concretization of religious freedom ${ }^{38}$. The Social Democrats were in favour of Naneishvili's project and opted for State secularism ${ }^{39}$.

The Georgian Church and Partiarch Leonide supported separation, but were against the French model of secularism, that was so popu-

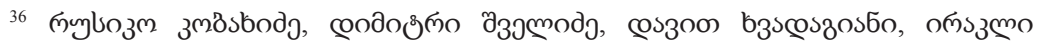

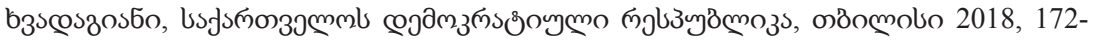
173 [Rusiko Kobakhidze, Dimitri Silakadze, David Khvadagiani, Irakili Khvadagiani, Democratic Republic of Georgia, Tbilisi 2018, 172-173].

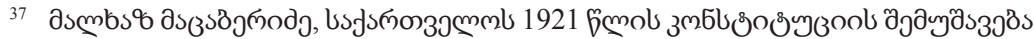

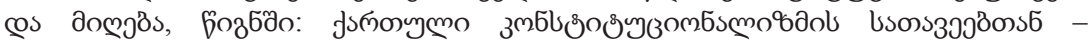

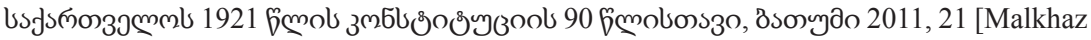
Matsaberidze, "Drafting and Adopting Constitution of Georgia of 1921", in: At the Beginning of Georgian Constitutionalism - 90 Anniversary of the Constitution of Georgia of 1921, Batumi 2011, 21].

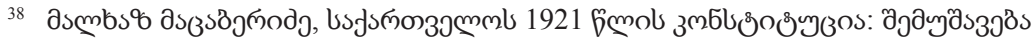

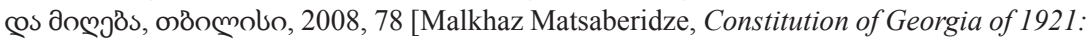
Drafting and Adopting, Tbilisi 2008, 78].

39 Ibid. 
lar in the Social Democrats ${ }^{40}$. The Church wanted to separate from the State, but collaborate in the future and implement the European model of church-state relations, which was more familiar to the people and in Georgian history.

The Social Democrats added a special article about funding religious organizations ${ }^{41}$. The National Democrats and independent members of the Constitutional Commission were against such clauses, but the Social Democrats had an absolute majority in the Commission and parliament, and therefore they passed the bill.

\subsection{THE CONTENT OF THE CONSTITUTIONAL PROVISIONS}

Article 31 of the Constitution of Georgia declared freedom of conscience and religion ${ }^{42}$. This provision prohibited any prosecution or restrictions for reasons of religion ${ }^{43}$. It declared that everyone had the right to profess their own religion, to change their religion, or not to have any religious creed $^{44}$. The Constitution separated religion from the sphere of interest of public authorities; according to the Basic Law, making use of religious freedom could not influence the scope of the civil rights or position of anybody ${ }^{45}$.

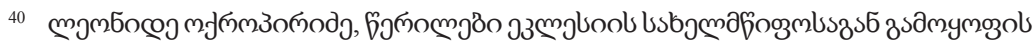

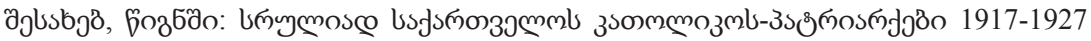

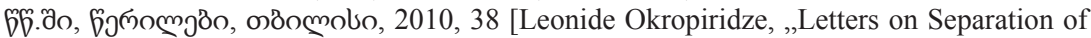
Church and State", in: Catholicos-Patriarchs of All Georgia in 1917-1927, Letters, Tbilisi 2010, 38].

41 Article 144 of Constitution of the Democratic Republic of Georgia of 21 February

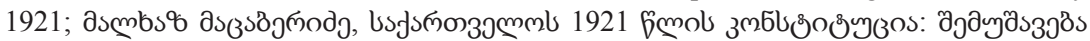

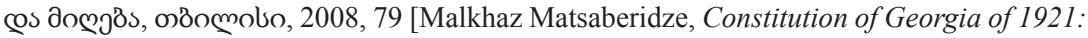
Drafting and Adopting, Tbilisi 2008, 79].

42 George Papuashvili, "The 1921 Constitution of the Democratic Republic of Georgia: Looking Back after Ninety Years”, European Public Law, 18/2 (2012), 337.

43 Second sentence, Article 31 of Constitution of the Democratic Republic of Georgia of 21 February 1921.

44 Ibid, third sentence.

45 Ibid, fifth sentence. 
The Georgian Church was not against this formulation; the spiritual leaders, the patriarch and the Church generally always advocated tolerance to other religions at that time ${ }^{46}$. The Church, as the main religious institution and representative of the largest group of the society, was a guarantee for other religions and religious entities ${ }^{47}$.

XVI chapter of the Constitution of 1921 regulated church-state relations. The chapter consisted of three articles and constituted the main framework for institutional relations and religious policy. Article 142 provided a basic idea of separation of Church and State, and guaranteed the institutional independence and autonomy for religious organizations without any interference in their internal affairs. This was an ideal formulation of the modern secular norm, but unfortunately, the reality was quite different. The Social Democratic government fought against religious organizations and especially against the Georgian Orthodox Church as the symbol of the former government and Empire ${ }^{48}$.

The ruling party tried to implement the state policy in the organizational structures of the Church and involve public jurisdiction in it. In consequence, the Church was against it. The National Democrats and their followers supported the Georgian Church in the battle with the government ${ }^{49}$. But they were the opposition and political minority so they did not have an important influence on the ongoing political processes in the country. During the Second Council of the Church, on 27 June 1920, the

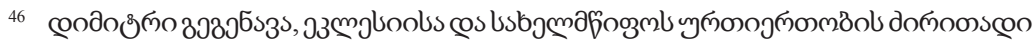

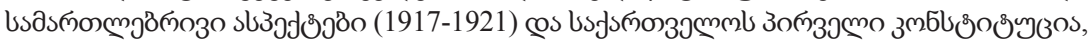

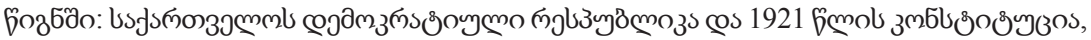

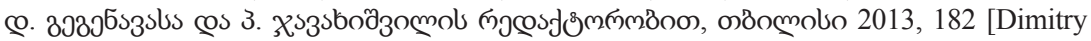
Gegenava, „Basic Legal Aspects of Relations Between Church and State (1917-1921) and First Constitution of Georgia”, in: Democratic Republic of Georgia and Constitution of 1921, edited by Dimitry Gegenava and Paata Javakhishvili, Tbilisi 2013, 182].

47 Ibid, 182-183.

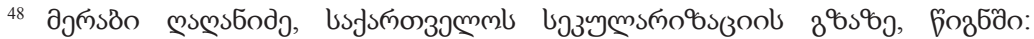

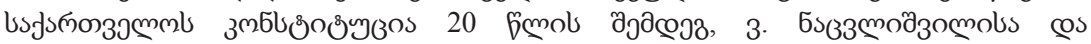

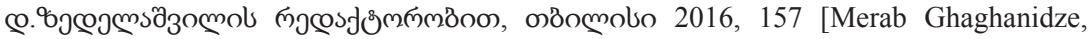
„Georgia on the Way of Secularization”, in: Constitution of Georgia after 20 years, edited by V. Natsvlishvili and D. Zedelashvili, Tbilisi 2016, 157].

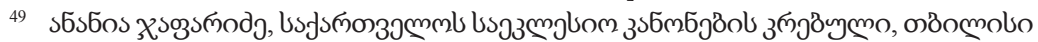
2010, 591 [Anania Japaridze, Code of Georgian Canon Laws, Tbilisi 2010, 591]. 
participants discussed the separation of Church and State and the process of secularization ${ }^{50}$. The Georgian Church was not against its peaceful coexistence with the State and supported the idea of separation. In reality, the democratic separation was not implemented in the First Republic, because the government theoretically aimed to guarantee religious freedom and institutional separation, but in practice it also wanted to control all the processes inside religious organizations.

Article 143 was part of the State's secular policy and explicitly provided that "no confession or creed enjoys special privileges". This is a demonstration of religious neutrality on the constitutional level and underlines the importance of equality under the law in terms of religion. Unlike the first Constitution, the current Constitution of Georgia declares the historical role of the Georgian Church and gives it the privilege to regulate its relations with a special document - Constitutional Agreement (Concordat $)^{51}$.

According to article 144, every state and municipal organs were prohibited to finance any religious organization for religious purposes. This provision is a classic norm of French secularism, which also prohibits transferring any kind of financial resources to religious entities. The Georgian Church was always a very strong and financially sustainable institution and it was not dependent on state funding: it had its property, lands, and donations from the people or nobility ${ }^{52}$. However, after implementing the anti-religious policy in the Democratic Republic of Georgia, the Church lost its property and the clergy did not have enough resources to live on. The situation was very dangerous for religious organizations and they were getting weaker and weaker as a result, which was the real goal of the government. Adopting this provision, the State cut the final resource for religious entities.

50 Ibid, 593-594.

51 Article 9(2) of Constitution of Georgia of 1995.

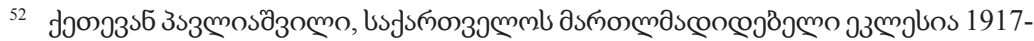

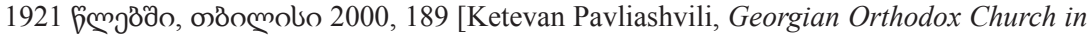
1917-1921, Tbilisi 2000, 189]. 


\section{CONCLUSION}

Every nation has its own way. On this way, everyone will meet one of the most important questions - how to organize church-state relations. In XXI century, the modern world knows: religion is a very personal category of human rights. Beliefs became a personal issue, but religious organizations, especially representatives of the majority, will find it difficult to accept their new functions and role in the society ${ }^{53}$. It is difficult even now, and we can only imagine how it was in 1918-1921. The Social Democratic government tried to implement the European ideology and principles in Georgia, but on the other hand, they did not realize the power of social institutions and traditions. It is impossible to overrule the ideas that used to be in practice for almost twenty centuries.

Reforming the State and society, the government of the Democratic Republic of Georgia declared war on religious institutions and pictured them as the most dangerous enemies. However, the reality was quite different. The real enemy was Bolshevism and the forces from the North. The national government seriously weakened religious organizations (but not religions), and the Communists easily finalized their work. In FebruaryMarch of 1921, Soviet Russia broke the agreement and occupied the independent Georgia. Because of the strictly secular policy, neither the Georgian Church nor other organizations could fight against the conquerors. The Bolsheviks just ended the work of the national government: churches did not have their property, treasure, or any other material resources. Moreover, the incredible repressions and attempts to defeat the last citadel in the country - the people - began at the time.

Church-state relations in the Democratic Republic of Georgia are a good example how utopic ideas can be painful and harmful for the society. Any model of secularism must be based on historical, economic and social grounds, and while evolution is a very difficult process, it is always more effective and involves fewer victims than revolution or revolutionary actions.

53 Victor Roudometof, "The Evolution of Greek Orthodoxy in the Context of World Historical Globalization", in: Orthodox Christianity in 21st Century Greece, The Role of Religion in Culture, Ethnicity and Politics, edited by Victor Roudometof and V.N. Makrides, Ashgate 2010, 31 . 


\section{REFERENCES}

Berichvili, Thierry. 2017. La social-démocratie géorgienne de 1880 à 1953 Quelques repères, Tbilissi.

Doe, Norman. 2013. Christian Law, Contemporary Principles, New York.

Gegenava, Dimit'ri. 2013. Ek'lesiisa da sakhelmts'ipos urtiertobis dziritadi samartlebrivi asp'ekt'ebi (1917-1921) da sakartvelos p'irveli k'onst'it'utsia, ts'ignshi: Sakartvelos demok'rat'iuli resp'ublik'a da 1921 ts'lis k'onst'it'utsia, d. gegenavasa da p'. javakhishvilis redakt'orobit, Tbilisi [Gegenava, Dimitry. 2013. "Basic Legal Aspects of Relations between Church and State (1917-1921) and First Constitution of Georgia", in: Democratic Republic of Georgia and Constitution of 1921, edited by Dimitry Gegenava and Paata Javakhishvili, Tbilisi]. Gegenava, Dimit'ri. 2016. K'onst'it'utsiuri shetankhmeba, rogorts ek'lesiasakhelmts'ipos urtiertobis samartlebrivi porma da misi aghsruleba sakartveloshi, Tbilisi [Gegenava, Dimitry. 2016. Constitutional Agreement, as Legal Form of Church-State Relations and Its Implementation in Georgia, Tbilisi].

Gegenava, Dimitry. 2014. „Les Bases Européennes Du Constitutionalisme Géorgien: La Lutte Pour Un Etat De Droit”, in: Valeurs et Identite Européennes, Texte des Conferences, Tbilissi.

Ghaghanidze, Merabi. 2016. Sakartvelos sek'ularizatsiis gzaze, ts'ignshi: Sakartvelos k'onst'it'utsia 20 ts'lis shemdeg, v. natsvlishvilisa da d.zedelashvilis redakt'orobit, Tbilisi [Ghaghanidze, Merab. 2016. "Georgia on the Way of Secularization", in: Constitution of Georgia after 20 years, edited by V. Natsvlishvili and D. Zedelashvili, Tbilisi].

Japaridze, Anania. 2010. Sakartvelos saek'lesio k'anonebis k'rebuli, Tbilisi [Japaridze, Anania. 2010. Code of Georgian Canon Laws, Tbilisi].

Japaridze, Anania. 2012. Sakartvelos samotsikulo ek'lesiis ist'oria, t'. IV, Tbilisi [Japaridze, Anania. 2012. History of the Georgian Apostolic Church, Vol. IV, Tbilisi].

Kantaria, Beka. 2012. Mmartvelobis pormis dasavluri sist'emebis gav-lena sakartvelos p'irvel k'onst'it'utsiaze, Tbilisi [Kantaria, Beka. 2012. Influence of Western Forms of Government on the First Constitution of Georgia, Tbilisi].

K'ek'elia, Tatia, Elene Gavashelishvili, K'onst'ant'ine Ladaria, Irina Sulkhanishvili. 2013. Martlmadidebeli ek' lesiis roli kartuli natsionaluri ident'obis chamoq'alibebashi (XX sauk'unis bolo-XXI sauk'unis dasats'q'isi), Tbilisi [Kekelia, Tatia, Elene Gavashelishvili, Konstantine Ladaria and Irina Sulkhanishvili. 2013. The Role of the Orthodox Church in the Establishment of the Georgian National Identity (End of XX Century-Beginning of XXI Century), Tbilisi. 
K'obakhidze, Rusik'o, Dimit'ri Shvelidze, Davit Khvadagiani, Irak'li Khvadagiani. 2018. Sakartvelos demok'rat'iuli resp'ublik'a, Tbilisi [Kobakhidze, Rusiko, Dimitri Silakadze, David Khvadagiani, and Irakili Khvadagiani. 2018. Democratic Republic of Georgia, Tbilisi].

Matsaberidze, Malkhaz. 2008. Sakartvelos 1921 ts'lis k'onst'it'utsia: shemushaveba da migheba, Tbilisi [Matsaberidze, Malkhaz. 2008. Constitution of Georgia of 1921: Drafting and Adopting, Tbilisi].

Matsaberidze, Malkhaz. 2011. Sakartvelos 1921 ts'lis k'onst'it'utsiis shemushaveba da migheba, tsignshi: kartuli k'onst'it'utsionalizmis sataveebtan sakartvelos 1921 ts'lis k'onst'it'utsiis 90 ts'listavi, Batumi [Matsaberidze, Malkhaz. 2011. "Drafting and Adopting Constitution of Georgia of 1921", in: At the Beginning of Georgian Constitutionalism - 90 Anniversary of the Constitution of Georgia of 1921, Batumi].

Okrop'iridze, Leonide. 2010. Ts'erilebi ek'lesiis sakhelmts'iposagan gamoq'opis shesakheb, ts'ignshi: Sruliad sakartvelos k'atolik'os-p'at'riarkebi 1917-1927 ts'ts'.shi, ts'erilebi, Tbilisi [Okropiridze, Leonide. 2010. "Letters on Separation of Church and State", in: Catholicos-Patriarchs of All Georgia in 19171927, Letters, Tbilisi].

Papuashvili, George. 2012. "The 1921 Constitution of the Democratic Republic of Georgia: Looking Back after Ninety Years", European Public Law, 18(2): 323-349.

P'avliashvili, Ketevan. 2000. Sakartvelos martlmadidebeli ek'lesia 1917-1921 ts'lebshi, Tbilisi [Pavliashvili, Ketevan. 2000. Georgian Orthodox Church in 1917-1921, Tbilisi].

Roudometof, Victor. 2010. "The Evolution of Greek Orthodoxy in the Context of World Historical Globalization", in: Orthodox Christianity in 21st Century Greece, The Role of Religion in Culture, Ethnicity and Politics, edited by Victor Roudometof and V.N. Makrides, Ashgate.

Surguladze, Ak'ak'i, P'aat'a Surguladze. 1991. Sakartvelos ist'oria, 1783-1990, Tbilisi [Surguladze, Akaki and Paata Surguladze. 1991. History of Georgia, 1783-1990, Tbilisi].

Vacheishvili, Aleksandre. 1948. Nark'vevebi kartuli samartlis ist'oriidan, t'. II, Tbilisi [Vacheishvili, Alexander. 1948. Outlines of the History of Georgian Law, Vol. II, Tbilisi].

Vardosanidze, Sergo. 2001. Sakartvelos martlmadidebeli samotsikulo ek'lesia 1917-1952 ts'lebshi, Tbilisi [Vardosanidze, Sergo. 2001. Georgian Orthodox Church in 1917-1952, Tbilisi]. 


\section{RELACJE PAŃSTWO -}

KOŚCIÓŁ W DEMOKRATYCZNEJ REPUBLICE GRUZJI (1918-1921)

\section{Streszczenie}

Na tle współczesnych jej państw, Demokratyczna Republika Gruzji (19181921) jawi się jako byt unikatowy. Pomimo historycznie utrwalonych związków pomiędzy Kościołem i Państwem, socjaldemokratyczny rząd zmienił oficjalną politykę i obrał model francuskiego sekularyzmu, co stało się sytuacją wyjątkową z uwagi na gruzińskie tradycje. Model ten został przyjęty w Konstytucji z $1921 \mathrm{r}$. Niniejszy artykuł poświęcony jest relacjom Państwo-Kościół w latach 1918-1921, $\mathrm{w}$ tym pozytywnym i negatywnym aspektom przyjętej formy sekularyzmu, a także wyzwaniom, przed jakimi stanęło niepodległe państwo w zakresie wolności religijnej do czasu sowieckiej okupacji.

Słowa kluczowe: Gruziński Kościół Prawosławny; separacja; Demokratyczna Republika Gruzji; wolność religii; sekularyzm; relacje Państwo-Kościół 